JSAP: Journal Syariah and Accounting Public

ISSN: 2622-3538

Available Online at https://journal.umgo.ac.id/index.php/JSAP/index

Vol. 3, No. 2 Desember 2020

DOI: $10.31314 /$ jsap.3.2.73-81.2020

\title{
PENGARUH PERILAKU PERANGKAT DESA TERHADAP KECENDERUNGAN FRAUD DANA DESA (Studi Kasus Pada Desa Di Kecamatan Pulubala)
}

\author{
Lukfiah I. Radjak ${ }^{1}$, Muhamad Taufik R Nani ${ }^{2}$ \\ 1, Program Studi Akuntansi, Universitas Muhammadiyah Gorontalo, Indonesia \\ 2, Program Sarjana Universitas Ichsan Gorontalo Indonesia \\ Email; lukfiahradjak@umgo.ac.id,
}

Info Artikel: Diterima: 13 Oktober 2020, Disetujui: 23 November 2020, Publish 15 Desember 2020

\begin{abstract}
:
This research is aimed at finding the influence of the behavior of village apparatus on the tendency of village fund fraud in the Pulubala Subdistrict. The object of this research is the villages in the Pulubala Subdistrict. The sampling technique used in this study is the saturated sampling technique. The research data is the primary data obtained by distributing questionnaires to 77 respondents. The results of this study indicate that the behavior of village apparatus has a negative but significant effect on the tendency of village fund fraud with a significance level at 0.000. It shows that the better the behavior of the village apparatus, the lower the tendency for village fund fraud. The implication of the results of this study is the need to apply an ethical culture within the village government organizations by providing understanding to village apparatus that fraud is an unethical and immoral act that can not only harm oneself because it can lead to criminal corruption cases with the threat of imprisonment and tarnished reputation, but it can also cause wider harm, namely the losses to the state and society.
\end{abstract}

Keywords: behavior, village apparatus, village funds, fraud

\begin{abstract}
Abstrak:
Tujuan dilakukannya penelitian ini adalah untuk mengetahui besarnya pengaruh perilaku perangkat desa terhadap kecenderungan fraud dana desa di Kecamatan Pulubala. Objek penelitian ini adalah desa-desa yang ada di Kecamatan Pulubala. Teknik pengambilan sampel yang digunakan dalam penelitian ini adalah dengan menggunakan teknik sampling jenuh. Data penelitian ini adalah data primer yang diperoleh dengan menyebarkan kuesioner pada 77 responden. Hasil penelitian ini menunjukkan bahwa perilaku perangkat desa berpengaruh negatif dan signifikan terhadap kecenderungan fraud dana desa dengan tingkat signifikansi sebesar 0,000 . Hal ini menunjukkan bahwa semakin baik perilaku perangkat desa, semakin rendah kecenderungan fraud dana desa. Implikasi dari hasil penelitian ini adalah perlu diterapkannya budaya etis di dalam organisasi pemerintah desa dengan memberikan pemahaman kepada para aparat desa bahwa tindakan fraud merupakan suatu tindakan tidak etis dan tidak bermoral yang tidak hanya dapat merugikan diri sendiri karena dapat mengantarkannya ke dalam kasus tindak pidana korupsi dengan ancaman penjara dan nama baik tercemar, tapi juga dapat menyebabkan kerugian yang lebih luas yaitu kerugian bagi negara dan juga masyarakat.
\end{abstract}

Kata kunci : perilaku, perangkat desa, dana desa, fraud 


\section{PENDAHULUAN}

Lahirnya Undang-undang No.6 Tahun 2014 tentang Desa disebutkan bahwa kucuran dana milyaran rupiah langsung ke desa itu bersumber dari alokasi dana desa yang juga merupakan bagian dari dana perimbangan yang diterima kabupaten/kota. Penyaluran dana tersebut menjadi sangat penting dalam rangka pembangunan desa yang lebih maju. Pada tahun 2019 berdasarkan data dari kementrian keuangan diketahui bahwa rata-rata setiap desa akan memperoleh dana sebesar Rp 933,92 juta. Besarnya anggaran yang diperoleh tiap desa ini jelas berpotensi untuk diselewengkan, sehingga menimbulkan kekhawatiran di banyak pihak.

Indonesia Corruption Watch (ICW) mencatat bahwa kasus korupsi anggaran dana desa merupakan salah satu kasus terbanyak yang saat ini sedang ditindaki oleh aparat penegak hukum selama tahun 2019 jika dibandingkan dengan sektor-sektor lainnya. Berdasarkan data Indonesia Corruption Watch (ICW) menunjukkan bahwa ada sebanyak 46 kasus korupsi anggaran dana desa yang terjadi selama tahun 2019 yang menyebabkan kerugian Negara hingga 32,3 miliar rupiah. Modus yang dilakukan oleh pelaku korupsi anggaran dana desa pun ada bermacammacam mulai dari penyalahgunaan anggaran, penggelapan anggaran, pembuatan laporan atau kegiatan fiktif sampai pada penggelembungan harga.

Fenomena tentang penyalahgunaan keuangan dana desa ini jelas menimbulkan kegundahan bagi masyarakat sebab praktik penyalahgunaan anggaran ini bisa di ibaratkan sebagai fenomena gunung es. Sebagaimana yang diungkapkan oleh Tuanakotta (2014) bahwa praktik fraud atau penyalahgunaan anggaran yang terungkap sekalipun secara absolut besar, namun jika dibandingkan dengan seluruh praktik fraud yang sebenarnya terjadi akan relative lebih kecil. Fraud triangle theory setidaknya menjelaskan ada 3 faktor yang mendorong terjadinya tindakan kecurangan yaitu tekanan (pressure), peluang (opportunity), dan rasionalisasi (rationalization). Fraud triangle theory ini kemudian dikembangkan dengan menambahkan satu elemen kualitatif yang diyakini turut berpengaruh signifikan terhadap fraud yaitu kemampuan (capability), sehingga menjadi empat elemen yang kemudian dikenal dengan fraud diamond (Wolfe dan Hermanson, 2014).

Fenomena pelanggaran moral dan etika yang sering kita amati dalam pemerintahan desa dapat berupa proses pembuatan kebijakan publik dalam pengusulan program, proyek, dan kegiatan yang tidak di dasarkan atas kenyataan desain organisasi pelayanan publik mengenai pengaturan struktur, formalitas, disperse otoritas terhadap kepentingan tertentu, proses manajemen pelayanan publik yang penuh rekayasa dan kamuflase mulai dari perencanaan teknis, pengelolaan keuangan, sumber daya manusia, informasi yang semuanya itu nampak dari sifat-sifat tidak transparan, tidak responsive, tidak akuntabel, dan tidak adil sehingga tidak dapat memberikan kualitas pelayanan yang unggul kepada masyarakat. Sehingga sudah sepatutnya pelayanan publik dilakukan secara beretika agar tidak adanya kekecewaan dalam suatu masyarakat. Sebagaimana dijelaskan oleh Manossoh (2016) bahwa pejabat yang memiliki perilaku yang baik akan membuat pengelolaan keuangan berjalan dengan baik dan begitupun sebaliknya.

Banyaknya berita terkait kecurangan dalam pengelolaan dana desa yang dilakukan oleh aparatur desa di surat kabar, televisi maupun media sosial memberikan 
kita kesadaran bahwa perlu adanya upaya untuk membenahi ketidak beresan yang terjadi. Apalagi diberbagai artikel diketahui bahwa terjadinya indikasi penyalahgunaan justru dilakukan oleh kepala desa dan aparat desa. Bahkan peningkatan jumlah kasus penyalahgunaan anggaran dana desa ini hampir berbanding lurus dengan berlakunya undang-undang baru anti tindakan kecurangan. Namun kenyataannya usaha yang dilakukan oleh pemerintah untuk memerangi tindakan kecurangan tidak berjalan dengan lancar dan hanya bersifat formalitas.

Sebagai salah satu kabupaten yang ada di Provinsi Gorontalo, Kabupaten Gorontalo pun tidak pernah luput dari adanya kasus penyelewenangan dana desa. Hal ini terbukti dari adanya berita penangkapan dari mantan kepala desa labanu kecamatan tibawa dan mantan kepala desa motoduto kecamatan boliyohuto atas kasus penyelewengan dana desa yang saat ini sudah dijebloskan ke dalam penjara. Keduanya ditahan setelah ditetapkan sebagai tersangka dugaan korupsi dana desa oleh kejaksaan negeri kabupaten gorontalo. Dugaan penyimpangan dana desa yang dilakukan pun hampir sama yaitu terkait dengan pelaksanaan pekerjaan fisik yang menggunakan dana desa namun tidak sesuai dengan spesifikasi dan rincian anggaran belanja (RAB). Selain itu ada juga indikasi pembuatan pelaporan penggunaan anggaran dana desa fiktif. Dalam artian kedua mantan kades ini membuat seolaholah ada kegiatan yang dibiayai oleh dana desa akan tetapi kenyataan dilapangan tidak ada kegiatan yang dilaksanakan. Akibat dari tindakannya tersebut Negara menanggung kerugian sebesar Rp 590 juta (sumber : Gopos.id). Hal ini diperkuat dengan pernyataan dari bapak Adam Hutamansyah selaku Kasie Datun Kejaksaan Negeri
Kabupaten Gorontalo didalam sebuah kanal youtube Kompas TV Gorontalo yang menyatakan bahwa saat ini tim penyidik masih sementara dalam tahap pemberkasan dan apabila tahap pemberkasan selesai kasus akan dilimpahkan ke penuntut umum untuk dilakukan penelitian berkas perkara dan dilimpahkan ke pengadilan dan saat ini kedua mantan kepala desa tersebut telah dilakukan penahanan selama 20 hari dan dapat diperpanjang oleh penuntut umum selama 40 hari kedepan. Akibat perbuatannya kedua tersangka dijerat dengan pasal 2 ayat 1 dan pasal 3 UndangUndang Tindak Pidana Korupsi dengan ancaman hukuman 5 tahun penjara (https://youtu.be/DHZFVUMqUHU).

Selain pernyataan dari bapak Adam Hutamansyah selaku Kasie Datun Kejaksaan Negeri Kabupaten Gorontalo, berdasarkan wawancara penulis dengan salah satu warga yang tidak ingin namanya diketahui membenarkan berita tersebut. Terlebih kata warga ini akibat kasus tersebut bahkan Bupati Gorontalo telah mengeluarkan surat keputusan pemberhentian sementara kepala desa labanu kecamatan tibawa dengan melampirkan petikan putusan No. 1/Pid.SusTPK/2020/PN Gto.. Berdasarkan fenomena yang diuraikan diatas, peneliti merasa tertarik untuk melakukan penelitian dengan judul "Pengaruh Perilaku Perangkat Desa Terhadap Kecenderungan Fraud Dana Desa Di Kecamatan Pulubala".

Adapun maksud dan tujuan dari penelitian ini adalah:

Penelitian ini dilakukan dengan maksud untuk memperoleh data-data dan juga informasi mengenai pengaruh perilaku perangkat desa terhadap kecenderungan fraud dana desa.

Sedangkan tujuan dilakukan penelitian ini adalah untuk mengetahui besarnya 
pengaruh perilaku perangkat desa terhadap kecenderungan fraud dana desa.

\section{METODE PENELITIAN}

Metode penelitian yang digunakan dalam penelitian ini adalah metode kuantitatif yaitu suatu metode yang menekankan pada pengujian teori-teori atau konsep melalui pengukuran variabel dan melakukan prosedur analisis data dengan peralatan statistic serta bertujuan untuk menguji hipotesis (Sugiyono, 2008). Berdasarkan jenisnya, penelitian ini tergolong dalam penelitian explanatory research. Penelitian eksplanasi digunakan untuk menganalisis hubungan-hubungan antara satu variabel dengan variabel lainnya atau bagaimana suatu variabel mempengaruhi variabel lainnya melalui pengujian hipotesis. Oleh karena itu, penggunaan metode ini diharapkan mampu memberikan pemahaman dan penalaran yang baik bagi hasil penelitian ini secara menyeluruh.

Adapun jenis data yang digunakan dalam penelitian ini adalah data kuantitatif yang berupa nilai atau skor atas jawaban yang diberikan oleh responden terhadap pertanyaan-pertanyaan yang ada dalam kuesioner. Sumber data yang digunakan dalam penelitian ini adalah data primer. Data ini langsung diperoleh dari penelitian lapangan melalui pengamatan langsung pada obyek yang akan diteliti melalui teknik pengumpulan data berupa wawancara, kuesioner dan observasi. Sementara untuk data yang berhubungan dengan data-data sekunder akan dilakukan melalui studi kepustakaan.

Metode analisis data yang digunakan dalam penelitian ini adalah analisis kuantitatif yang dilakukan dengan membahas dan membuat presentase dari hasil jawaban responden. Untuk mendapatkan data yang baik dalam arti mendekati (objektif) sudah tentu diperlukan suatu instrument atau alat ukur yang valid dan andal, maka instrument tersebut sebelum digunakan harus di uji validitas dan realibilitasnya sehingga apabila digunakan akan menghasilkan hasil yang objektif.

Untuk memastikan apakah ada pengaruh variabel deteksi perilaku perangkat desa $\left(X_{1}\right)$ terhadap kecenderungan fraud dana desa $(Y)$. maka pengujian dilakukan dengan uji analisis regresi sederhana dengan terlebih dahulu mengkonversi data skala ordinal ke skala interval. Analisis regresi sederhana sebagai berikut :

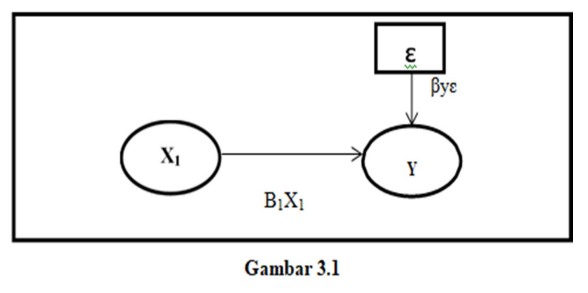

Struktur Analisis Regresi Linear Sederhana

Dari gambar diatas dapat dilihat dalam persamaan berikut :

$$
\begin{aligned}
& Y=\alpha+\beta_{1} X_{1}+\varepsilon \\
& \text { Keterangan : } \\
& Y \text { : Penyimpangan Dana Desa } \\
& X 1 \text { : Perilaku Perangkat Desa }
\end{aligned}
$$


$\beta_{1}$ : Koefisien Regresi

$\varepsilon$ : Standar Eror

Metode statistik yang digunakan untuk menguji hipotesis yaitu dengan menggunakan regresi linear sederhana dengan bantuan perangkat lunak SPSS for windows sebagai berikut :

1. Uji Statistik Deskriptif

Statistik deskriptif memberikan gambaran atau deskripsi suatu data yang dilihat dari nilai rata-rata (mean), standar deviasi, varian, maksimum, minimum, sum, range, kurtosis dan skewness (Ghozali, 2009).

2. Uji Persamaan Regresi Linear Sederhana

Pengujian hipotesis ini dilakukan dengan menggunakan metode analisis regresi linear sederhana. Analisis regresi linear sederhana ialah suatu alat analisis peramalan nilai pengaruh variabel bebas terhadap variabel terikat untuk membuktikan ada atau tidaknya hubungan fungsi atau hubungan kausal variabel bebas (Riduwan, 2010).

\section{a. Uji Statistik $t$}

Uji statistik dilakukan dengan menggunakan uji t yaitu uji yang bertujuan untuk melihat pengaruh dari variabel independen secara individu terhadap variabel dependen. Jika tingkat signifikansi uji $\mathrm{t}$ lebih kecil dari 5\% maka terdapat pengaruh yang signifikan dari variabel independen terhadap variabel dependen dan sebaliknya.

\section{b. Uji Koefisien Determinasi $\left(R^{2}\right)$}

Menurut Ghozali (2011) koefisien determinasi intinya mengukur atau melihat seberapa jauh kemampuan model dalam menerangkan variasi variabel dependen. Bila $\mathrm{R}^{2}$ kecil maka kemampuan variabel untuk menjelaskan variasi variabel sangat terbatas, sedangkan $\mathrm{R}^{2}$ sama dengan satu, maka variabel independen berpengaruh secara sempurna terhadap variabel dependen.

Dalam penelitian ini penulis menggunakan perangkat komputer untuk melakukan pengolahan data dengan menggunakan program SPSS versi 24 dibantu dengan program MS. Excel.

\section{HASIL DAN PEMBAHASAN}

Populasi dan sampel dalam penelitian ini adalah seluruh perangkat desa yang ada di Kecamatan Pulubala. Dari 11 desa yang terdapat di Kecamatan Pulubala ada 77 sampel yang akan digunakan dan yang menjadi sumber data dalam penelitian ini adalah seluruh perangkat desa yang meliputi kepala desa, sekretaris, kasie keuangan, kasie pembangunan, kasie pemerintahan, kasie umum dan kasie sosial. Data penelitian yang dikumpulkan berupa kuesioner yang disebarkan langsung ke seluruh responden atau perangkat desa yang bersangkutan. Kuesioner tersebut ditinggal dan diambil kembali antara 2 hari sampai 1 minggu setelah kuesioner diserahkan.

Dari serangkaian penelitian yang telah dilakukan maka dapat dijabarkan beberapa hasil uji berikut: 
1. Hasil Uji Regresi Linier Sederhana

Tabel 4.12 Model Persamaan Regresi

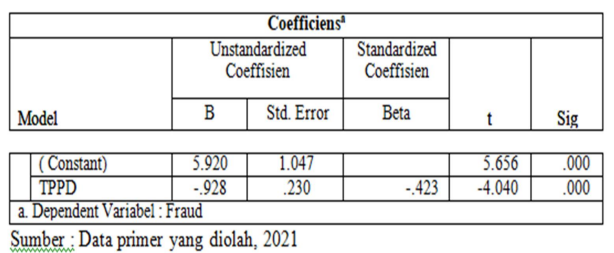

Berdasarkan tabel 4.12 diatas, maka persamaan regresi yang terbentuk pada uji regresi ini adalah :

\section{$\mathrm{Y}=\mathbf{5 . 9 2 0}-0.928 \mathrm{X}_{1}+\mathrm{e}$}

Model tersebut dapat diinterpretasikan sebagai berikut :

a. Nilai konstanta adalah 5.920 ini menunjukkan bahwa jika variabel independen (perilaku perangkat desa) bernilai (0), maka nilai variabel dependen (kecenderungan fraud dana desa) sebesar 5.920 satuan.

b. Koefisien regresi perilaku perangkat desa $\left(b_{1}\right)$ adalah -0.928 dan bertanda negative. Hal ini berarti nilai variabel $\mathrm{Y}$ akan mengalami penurunan sebesar 0.928 jika nilai variabel $X_{1}$ mengalami kenaikan satu satuan dan variabel independen lainnya bernilai tetap. Koefisien bertanda negative menunjukkan adanya hubungan yang berlawanan antara variabel perilaku perangkat desa $\left(\mathrm{X}_{1}\right)$ dengan variabel kecenderungan fraud dana desa $(Y)$. Semakin baik perilaku perangkat desa maka semakin rendah kecenderungan fraud dana desa.

2. Hasil Uji $R^{2}$ (Koefisien Determinasi)

Tabel 4.13 Hasil Uji $\mathrm{R}^{\text {? }}$

\begin{tabular}{|l|l|r|r|r|}
\hline \multicolumn{5}{|c|}{ Model Summary $^{\mathrm{b}}$} \\
\hline & & & Std. Eror of \\
Model & $\mathrm{R}$ & R Square & $\begin{array}{c}\text { Adjusted R } \\
\text { Square }\end{array}$ & \\
\hline 1 & $.423^{\mathrm{a}}$ & .179 & .168 & .65733 \\
\hline
\end{tabular}

a.Predictors : (Constant), perilaku perangkat desa,

b Dependent Kecenderungan fraud dana desa

Sumber: Data primer yang diolah, 2020
Dari tabel 4.13 diatas terdapat angka $\mathrm{R}$ sebesar 0.423 yang menunjukkan bahwa hubungan antara kecenderungan fraud dana desa dengan variabel independennya tidak terlalu kuat karena angkanya berada di atas 0.4 . Sedangkan nilai $R$ Square sebesar 0.179 atau $17.9 \%$ ini menunjukkan bahwa variabel kecenderungan fraud dapat dijelaskan oleh variabel perilaku perangkat desa sebesar $17.9 \%$ sedangkan sisanya $82.1 \%$ dapat dijelaskan oleh variabel lain yang tidak terdapat pada penelitian ini.

3. Hasil Uji Parsial (uji t)

Uji parsial digunakan untuk melihat pengaruh variabel independen terhadap variabel dependen. Pengujian dilakukan dengan uji $t$ yaitu dengan melihat nilai signifikansi t hitung, jika nilai signifikansi < dari 0.05 maka dapat dikatakan variabel independen tersebut mempunyai pengaruh terhadap variabel dependen. Melalui statistik uji-t yang terdiri dari perilaku perangkat desa (X) diketahui secara parsial pengaruhnya terhadap kecenderungan fraud dana desa (Y).

Berdasarkan hasil uji diatas maka dapat dinyatakan bahwa perilaku perangkat desa memiliki pengaruh secara parsial dan signifikan terhadap kecenderungan fraud dana desa. Nilai $\mathrm{t}$ yang bernilai -4.040 menunjukkan pengaruh yang diberikan bersifat negative terhadap variabel dependen.

\section{Literature Review}

Teori yang digunakan dalam penelitian ini adalah Fraud diamond theory. Fraud diamond theory merupakan pengembangan teori yang dilakukan oleh cressey (1950) yakni teori segitiga kecurangan (fraud triangle), dalam risetnya menyebutkan bahwa kecurangan terjadi pada saat pelaku memiliki masalah financial yang sulit untuk diselesaiakan secara kolektif, yang 
menyebabkan persoalan tersebut harus diselesaikan secara terselubung dengan memanfaatkan kekuasaan atau posisi jabatan yang di emban dan membuat paradigma kepada khalayak bahwa mereka sebagai orang yang dipercayai untuk mengelola harta tersebut. sementara Wolfe and Hermanson (2004) melakukan pengembangan theory yang sama dengan menambah variabel lainya yakni variabel kemampuan (Capability).

Banyak motif dan dorongan yang sering timbul pada pelaku tindak kecurangan diantaranya adanya tekanan yang dirasakan, baik tekanan lingkungan, orang lain bahkan tekanan dari diri sendiri. Selain itu kecurangan terjadi pada saat ada peluang dan kesempatan, buruknya sistem pengendalian intern, meningkatnya perilaku by stander effect, dan masih banyak faktor faktor pendorong kecurangan dan pelaku kecurangan akan selalu melakukan pembenaran atas tindakan yang dilakukannya, dengan membuat dalil penafsiran aturan yang dilakukanya sendiri, kecurangan pun terjadi pada saat pelaku memiliki kemampuan dalam hal penafsiran aturan yang ada.

Ada empat elemen utama dalam Fraud diamond theory diantaranya adalah tekanan, peluang, rasionalisasi hingga kemampuan, ke empat elemen ini merupakan indikator pengukuran kecurangan berdasarkan fraud diamond theory. Elemen tekanan ditunjukkan dengan variabel kesesuaian kompensasi, elemen peluang ditunjukkan dengan variabel keefektifan pengendalian internal, elemen rasionalisasi ditunjukkan dengan variabel budaya etis organisasi, dan elemen kemampuan ditunjukkan dengan variabel ketaatan aturan akuntansi. Dari teori yang digunakan diatas, penelitian ini menghasilkan temuan sebagai berikut:
Hasil penelitian menunjukkan bahwa perilaku perangkat desa berpengaruh negative dan signifikan terhadap kecenderungan fraud dana desa di Kecamatan Pulubala. Hal ini menunjukkan bahwa semakin baik perilaku perangkat desa maka kecenderungan fraud dana desa bisa semakin berkurang. Teori yang sering digunakan untuk menjelaskan kecenderungan fraud dana desa adalah teori fraud diamond. Fraud diamond teori ini menekankan pada motif seseorang untuk melakukan suatu tindakan baik itu tindakan untuk tetap patuh pada aturan seperti mengikuti SOP (Standar Operasional Prosedur) yang ada atau sebaliknya, menyimpang dari jalur yang sebenarnya.

Implikasi dari penelitian ini adalah tentang bagaimana pressure (tekanan) dapat memotivasi seseorang untuk bertindak negative, tekanan ini bisa berasal dari atasan seperti adanya kewajiban upeti, menyetor sejumlah dana kepada pimpinan atau instansi lain yang terkait sebagai balas jasa karena telah memperjuangkan anggaran dari suatu proyek pekerjaan. Opportunity (kesempatan/peluang) berkaitan dengan lemahnya pengendalian internal atau tidak berjalan sebagaimana mestinya atau adanya hubungan internal antara penyedia barang dan kontraktor sehingga menjadi celah bagi pelaku untuk merekayasa pemenangan tender, memanipulasi harga, gratifikasi terkait perizinan, ketidaksesuaian spesifikasi terhadap pengadaan barang jasa. Rasionalisasi pada proses pengadaan akan berdampak pada pemikiran bahwa tindakan fraud yang dilakukan merupakan tindakan yang sudah umum dilakukan oleh kebanyakan orang.

Dalam pelaksanaan pengelolaan dana desa, ada beberapa desa yang masih tidak memenuhi amanat Peraturan Pemerintah 
Dalam Negeri Nomor 113 Tahun 2014 tentang pengelolaan keuangan desa dan masih sangat jauh dari apa yang diharapkan. Keadaan ini dapat dilihat dan dipahami dari segi perencanaan-perencanaan pemerintah desa dimana kepala desa sebagai pemegang kekuasaan pengelolaan keuangan dan asset desa dalam menetapkan anggaran pendapatan dan belanja desa yang seharusnya melibatkan komponen-komponen masyarakat namun lebih banyak ditangani oleh kepala desa sendiri, kemudian dalam hal pengajuan pendanaan untuk melaksanakan kegiatan yang harus disertai dengan dokumen antara lain seperti rancangan anggaran biaya namun pada kenyataannya tidak dilakukan sesuai dengan peraturan yang telah ditetapkan. Potensi kecurangan tersebut timbul karena sifat rasionalisasi pelaku yang menganggap wajar kesalahan dan pengawasan yang kurang. Pelaku kecurangan melakukan kecurangan karena sikap mereka yang menganggap wajar kecurangan yang mereka lakukan (Kurniawan, 2013). Kecurangan yang dilakukan di lingkup internal yang pengawasannya kurang memiliki kecenderungan yang tinggi untuk melakukan kecurangan lebih dari satu kali (Udayani \& Sari, 2017). Potensi kecurangan tersebut terjadi dalam tahap pertanggungawaban pengelolaan keuangan desa. Kesalahan yang sering terjadi dan dianggap wajar adalah kesalahan dalam hal administrative seperti penyusunan laporan pertanggungjawaban (LPJ) yang salah dan dokumen pendukung laporan keuangan yang kurang. Hal ini dibenarkan dalam Peraturan Menteri Dalam Negeri No. 20 Tahun 2018 tentang pengelolaan keuangan desa dimana lampiran atau dokumendokumen pendukung harus disertakan sesuai peraturan menteri. Pengendalian untuk mencegah potensi kecurangan ini adalah dengan meningkatkan nilai moral dan etika dari seluruh perangkat desa agar lebih berintegritas.

\section{KESIMPULAN}

Berdasarkan hasil penelitian dan pembahasan maka dapat ditarik kesimpulan bahwa perilaku perangkat desa berpengaruh negative dan signifikan terhadap kecenderungan fraud dana desa. Semakin baik perilaku perangkat desa maka semakin rendah kecenderungan fraud dana desa. Implikasi dari hasil penelitian ini adalah perlu diterapkannya budaya etis di dalam organisasi pemerintah desa dengan cara meyakinkan para aparat desa bahwa tindakan fraud merupakan suatu tindakan non etis dan tidak bermoral merupakan kesalahan yang merugikan tidak hanya bagi dirinya karena dapat mengantarkannya ke dalam kasus tindak pidana korupsi dengan ancaman hukuman penjara dan nama baik tercemar tapi juga pada kerugian yang lebih luas yaitu kerugian bagi negara dan masyarakat.

\section{SARAN}

Berdasarkan hasil penelitian mengenai pengaruh perilaku perangkat desa terhadap kecenderungan fraund dana desa pada yang ada di Kecamatan Pulubala, maka hal-hal yang dapat disarankan sebagai berikut:

1. Bagi pemerintah desa diharapkan dapat membuat peraturan terkait budaya etis dalam organisasi secara jelas dan spesifik. Hal ini dilakukan agar setiap pengelola keuangan desa dapat mengetahui peraturan etis dan menentukan prilaku yang boleh dilakukan dan tidak boleh dilakukan sebagai seorang pengelola keuangan desa.

2. Bagi peneliti selanjutnya diharapkan dapat mengembangkan penelitian 
yang serupa dengan menambahkan variabel-variabel lain yang tidak terdapat dalam penelitian ini. selain itu, peneliti selanjutnya diharapkan dapat mengembangkan daerah survey dan menambahkan jumlah responden sebagai objek penelitian:

\section{REFERENSI}

Cressy, D. R., 1950. The Criminal Violation Of Financial Trust. American Sociological Review, 15(6), pp. 738743, Desember, pp. 1-15. Retrieved form www.JSTOR.org

Ghozali, I. 2009. Aplikasi Analisis Multivariate Dengan Program SPSS. Semarang : Badan Penerbit Universitas Diponegoro

Kurniawan, G. (2013). Pengaruh moralitas, motivasi dan sistem pengendalian intern terhadap kecurangan laporan keuangan (Studi empiris pada SKPD di kota Solok). Jurnal Akuntansi, 1(3).

Manossoh, H. 2016. Faktor-Faktor Penyebab Terjadinya Fraud Pada Pemerintah Di Provinsi Sulawesi Utara, Emba. Jurnal Mahasiswa Universitas Sam Ratulangi Manado, 4(1), 484-495

Peraturan Mentei Dalam Negeri Republik Indonesia Nomor 20 Tahun 2018 tentang Pengelolaan Keuangan Desa.

Peraturan Menteri Dalam Negeri No. 113 Tahun 2014 tentang Pedoman Pengelolaan Keuangan Desa

Riduwan. 2010. Skala Pengukuran VariabelVariabel Penelitian. Bandung : Alfabeta

Sugiyono. $\left(2018^{\mathrm{e}}\right)$. Metode Penelitian Kuantitatif, Kualitatif dan R\&D. Bandung CV. Alfabeta.

Sulina, T.,Wahyuni, M.A., \& Kurniawan, P.S. (2017). Peranan Sistem Keuangan Desa (Siskeudes) Terhadap Kinerja Pemerintah Desa (Studi Kasus di Desa
Kaba-Kaba, Kecamatan Kediri, Kabupaten Tabanan). Jurnal Akuntansi $8(2), 1-12$.

Sugiyono, 2008. Metode Penelitian Bisnis. Alfabeta : Bandung

Tuanakotta, T. M. 2014. Akuntansi Forensik Dan Audit Investigatif. Jakarta : Salemba Empat

Udayani, A. A. K. F., \& Sari, M. M. R. (2017). Pengaruh pengendalian internal dan moralitas individu pada kecenderungan kecurangan akuntansi. E-jurnal Akuntansi, 18(3), 1774- 1799.

Undang-Undang Nomor 6 Tahun 2014 Tentang Desa

Wolfe, D.T., \& Hermanson, D.R. 2014. Print The Fraud Diamond: Considering The Four Element Of Fraud. 12 (Exhibit 1), 1-5. 